\title{
Grit-ability: Which Grit Characteristics Enable Success for Mothers Entering University?
}

\author{
Anne Braund \\ CQUniversity, Australia \\ Trixie James \\ CQUniversity, Australia \\ Katrina Johnston \\ CQUniversity, Australia \\ Louise Mullaney \\ CQUniversity, Australia
}

\begin{abstract}
Personal characteristics contributing to success in higher education has become an important area of focus in recent years. Duckworth's (2007) grit framework shows positive correlations with a range of academic outcomes. This article explores the characteristics of grit in a study of female students who identified as mothers during their enrolment in an enabling program at CQUniversity Australia. Data was gathered from 284 participants and findings suggest that despite mothers facing competing challenges that conflict with study; demonstrating grit-ability is what enables success. The courage to begin; conscientious determination to achieve; resilience to overcome obstacles; endurance to persist; and striving for excellence were identified as key contributors to positive academic outcomes and personal fulfilment. Framework Methodology underpinned this thematic analysis using the grit terms of reference to examine survey responses. These findings highlight the relevance of grit as desirable student characteristics for experiencing success in enabling education.
\end{abstract}

Keywords: Grit; enabling education; grit-ability; student mothers; equity; resilience; endurance.

\section{Introduction}

Australian universities articulate support for student equity to ensure all groups of society have the opportunity to participate successfully in higher education. Enabling programs offer access to higher education; increasing enrolments from nontraditional students. Mothers are one of these non-traditional groups who seek an enabling course as their gateway to a new career and a better future for themselves and their families. Many mothers commencing enabling studies feel underprepared and lacking in confidence to navigate the academic landscape. This article will identify and discuss the personal characteristics that these mothers perceived empowered them to stay or leave. Each participant of this study identified as a mother whilst enrolled in the enabling course, Skills for Tertiary Education Preparatory Studies (STEPS) at CQUniversity Australia between 2012 and 2017. This research uses Duckworth's (2007) grit framework to examine the characteristics that the mothers identified as helping them overcome challenges and achieve success in their studies. A thematic analysis identifies common themes and ranks which grit characteristics were most recognisable in supporting mothers' successful engagement within this enabling course.

This work is licensed under a Creative Commons Attribution 4.0 International Licence. As an open access journal, articles are free to use with proper attribution. ISSN: 2205-0795 


\section{Literature Review}

Grit has been defined as demonstrating personal characteristics of passion and perseverance towards accomplishing long-term goals, whilst maintaining effort and interest to overcome challenges (Duckworth, Peterson, Matthews \& Kelly, 2007). Individuals possessing high levels of grit have been found to stay focused on their goals, even when faced with adversity (Duckworth, Quinn \& Seligman, 2009). Understanding personal characteristics that influence student behaviour is fundamental to supporting success in enabling education. Many Australian universities offer enabling programs as a pathway for nontraditional, marginalised groups to access higher education (Baker \& Irwin, 2014; Pitman, Roberts, Bennett \& Richardson, 2017). Universities Australia (2019) summarised that from 2008 to 2017, students entering university were increasingly from non-traditional backgrounds; reporting a 66 per cent increase in enrolments of students with low socioeconomic status (SES) (p. 15). CQUniversity Australia shows a growing number of low SES students in comparison to the Group of Eight (G08) coalition of Australia's leading universities (National Centre for Student Equity in Higher Education, 2019, p. 1) (see Figure 1).

\section{Figure 1}

Low SES Students at CQUniversity Comparison to Go8 Australian Universities

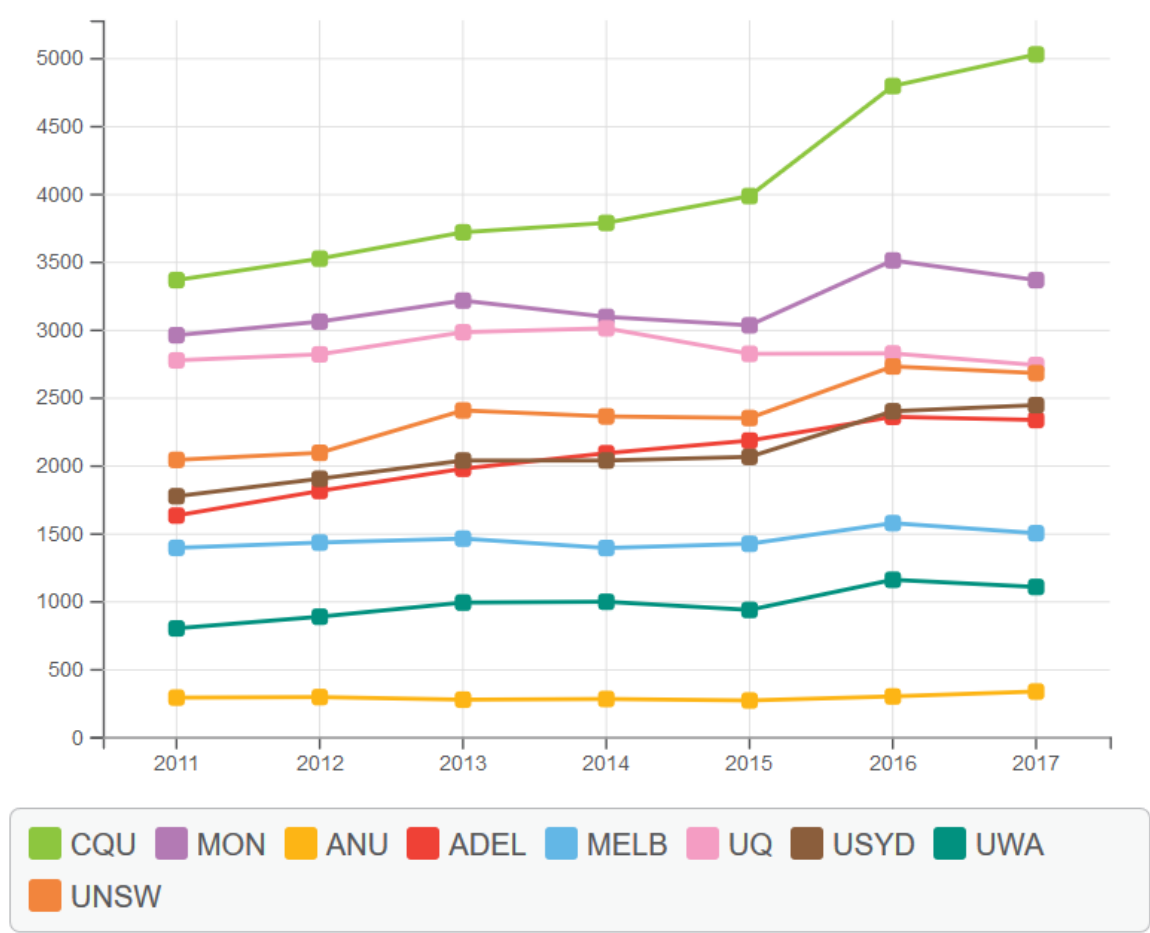

CQUniversity's enabling education course STEPS, supports a significant number of students from non-traditional backgrounds (Department of Education and Training, 2018, p. 1). With female enrolments at 58.3 per cent of all domestic students (Universities Australia, 2019, p. 9), mothers are a growing population within the larger non-traditional student groups entering university via enabling pathways. Mothers face unique challenges whilst undertaking their studies due to competing discourses: household duties, childcare, lack of support, poor self-belief, financial stress and time limitations (Johnston, James, Braund \& Mullaney, 2018, p. 17). Understanding the characteristics of non-traditional female students is fundamental to supporting their academic success (Auguste, Wai-Ling-Packard \& Keep, 2018). Researchers reasoned that non-traditional female students who enrolled in higher education were cognisant that study demands would impact on their other roles and consciously applied additional strategies to combat these competing commitments (Carney-Crompton \& Tan, 2002; Hardin, 2008; Quimby \& O'Brien, 2006; Wild, 2014). Furthermore, Jones (2018) suggested that women were more likely to take advantage of available resources to be successful; seeking career advice, joining social clubs to get connected, and gathering knowledge from other students to help them navigate achievement (Wallace, 2015). 
CQUniversity has educational and administrative systems to support student success and retention; however, further identification of individual student characteristics is valuable to improve support structures within enabling education. Individual student traits have been the focus of research around support and retention strategies in higher education, with grit characteristics identified as a significant contributor to academic success (Buskirk-Cohen \& Plants, 2019; Duckworth et al., 2007). Buskirk-Cohen and Plants (2019) claimed that understanding grit characteristics is particularly important in supporting the academic success of minority students in higher education.

Duckworth (2007) has become renowned for her grit framework of personality characteristics defined by an individual's "perseverance and passion for long-term goals" and "effort and interest over years despite failure, adversity, and plateaus" (pp. 1087-1088). Grit's suite of behaviours has shown a positive relationship with achievement, particularly in challenging academic domains (Duckworth et al., 2007; Duckworth et al., 2009). Bashant (2014) argues that Duckworth's (2007) grit concepts are key drivers of academic success and demonstrated "incremental predictive validity of success measures over and beyond IQ" (Buskirk-Cohen \& Plants, 2019, p. 109). In addition, grit characteristics encapsulate an individual's capacity to adapt when presented with challenging circumstances (Hodge, Wright \& Bennett, 2017) and influence an individual's motivation and persistence to successfully accomplish a goal (Bashant, 2014). Duckworth's (2007) research concluded that grit's multi-dimensional group of non-cognitive personality traits, lead some students to be more successful than others: courage, conscientiousness, resilience, endurance, and excellence.

\section{Courage}

The personality trait of courage is required to learn, develop, take risks and adjust to a changing world (Wallace, 2015). Courage was described as an abstract concept; actioned when people were faced with apprehension, fear, anxiety and uncertainty (Wallace, 2015). Physical and psychological courage were differentiated by an individual's ability to confront physically destructive habits, whilst applying mental strength to persevere (Lopez, O'Byrne \& Petersen, 2003). Further, Perlis (2013) conveyed that a person's ability to take risks and adapt is relative to their individual courage and a direct predictor of success.

\section{Conscientiousness}

This personality construct is observed through individual differences in self-control, responsibility, diligence, organisation and compliance (Roberts, Lejuez, Krueger, Richards \& Hill, 2014). This trait is reflected in an individual's thinking, feeling and behavioural patterns and has emerged as "the personality trait most consistently and strongly related to academic success" (Poropat, 2009, p. 30). Conscientiousness was described as the key element of grit that facilitated goal-related and achievementoriented behaviour (John, Naumann \& Soto, 2008).

\section{Resilience}

An individual's ability to succeed despite obstacles; self-confidence, motivation, well-being, goal-orientated, connectedness are integral components of resilience (Buskirk-Cohen \& Plants, 2018; Wallace, 2015). Resilient students demonstrated optimism, self-assurance and creative learning strategies when faced with adversity (Wallace, 2015). Zolli and Healy (2012) described resilience as an individual's capacity to uphold their core purpose, goals and integrity when presented with unforeseen interferences. Similarly, Cicchetti (2013) claimed resilience demonstrated the ability to use multidimensional constructs to overcome complex situations.

\section{Endurance}

Enduring perseverance is demonstrated through maintained focus, determination and persistence towards achieving long-term goals (Nagaoka et al., 2013). Endurance influences an individual's commitment towards achieving success; where students relinquish distractions in order to stay focused and prioritise higher pursuits (Farrington, et al., 2012). Persistent individuals were described as passionate with staying power and Doskoch (2016) asserted that endurance may be the foundation of grit. Jones (2018) noted that endurance was supported by individual determination, identified goals and motivation towards achieving success. Hagedorn (2006) concluded that student perseverance and endurance positively correlated with student success. 


\section{Excellence}

The characteristic of excellence inspires an individual's subconscious drive to pursue quality achievement (Duckworth et al., 2007). Excellence is described as an attitude; seeking fulfilment of purpose, an ongoing quest for improvement, with the flexibility to embrace failure along the journey (Perlis, 2013). Excellence is demonstrated in an individual's pursuit of goals that were neither too easy nor too challenging, with the individual highly motivated towards accomplishment and success (Duckworth et al., 2007; Perlis, 2013).

Duckworth, Quinn and Seligman (2009) maintained that applying the five grit characteristics combined with sustained zeal and hard work, predicted achievement in academic learning environments (Wallace, 2015). Additionally, the characteristics of grit frame a student's ability to take risks; determination to achieve; optimism in the face of setbacks; enduring perseverance; and an attitude of striving for success (Duckworth et al., 2007). Researchers agreed that demonstrating grit traits enabled students to succeed at higher-order goals and to persist long-term when encountering challenges throughout education and life (Shechtman, DeBarger, Dornsife, Rosier \& Yarnall, 2015).

Many researchers noted a link between grit and success within a wide range of academic settings (Bowman, 2015; Wolters \& Hussain, 2015). Studies have shown that students who demonstrated advanced levels of grit attained productivity, sustained motivation and achievement (Hodge et al., 2017; Kannangara et al., 2018; Pate et al., 2017) with some research reporting a positive correlation to higher grades (Cross, 2014; Wolf, 2015). Along with academic perspectives on grit, popular media has framed these traits as essential characteristics for healthy, productive development and necessary for achieving academic success (Gray, 2016). Interestingly, research by Kannangara et al (2018) showed a correlation between grit and gender, reporting a positive relationship between grit and grade point average; only present in females. Furthermore, female students demonstrated higher levels of grit characteristics (Kannangara et al., 2018) and maintained significantly higher interest levels than males (Cross, 2014). Still, other research has found no gender differences and contend that grit was not a significant contributor to positive academic outcomes (Bazelais, Lemay \& Doleck, 2016; Ivcevic, 2014; Stewart, 2015; West, 2015). Researchers also acknowledged that previous education experiences influenced grit, having an ongoing impact on a student's academic outcomes (Bazelais et al., 2016). Researchers also noted that grit characteristics are entwined with other personality traits and that these variables may sometimes mask its effects (Hodge et al., 2017).

\section{Methodology}

Transformative learning theory underpins this research recognising that academic learning environments, specifically, enabling education can be an impetus for driving personal perspective and behavioural transformation (Mezirow \& Taylor, 2011). When a person is faced with disorienting learning experiences, there is a paradigm shift in their perspectives of the world (Khabanyane, Maimane \& Ramabenyane, 2014). An individual's perspective transformation enhances one's understanding of themselves; questions their existing belief systems; and motivates behavioural changes to fit with their new identity (Mezirow \& Taylor, 2011). This transformation motivates personal change where adults adapt old ways of making meaning to new perspectives that meet current environments (Khabanyane et al., 2014). Transformative learning theory involves a developmental process where personal and collective unconsciousness, become intentional and are assimilated into the whole personality (Enkhtur \& Yamamoto, 2017). These transformations often occur in university environments where students are learning new ideas, critically analysing their own beliefs and engaged in scholarship with their peers (Howie \& Bagnall, 2013). Transformative learning theory links appropriately to describe the perspectives of the mothers in this study.

\section{Participants}

The data used in this article investigated the experiences of mothers enrolled in the STEPS enabling course at CQUniversity, Australia wide. Researchers emailed a survey to 5880 female students who were enrolled in part-time or full-time, on-campus or online study between 2012 and 2017. From the 410 responses, 284 students identified as mothers and completed an online survey. The demographic profile of these 284 mothers was varied: age range (19 to 64 years); number of children in their care (one through to seven); marital status (married, sole parent, de facto and other); and current study position (97 were currently enrolled in the STEPS enabling program; 130 had progressed to undergraduate studies or graduated; four participants had moved onto vocational education pathways and 53 were not currently engaged in higher education) (see Figure 2). 


\section{Figure 2}

\section{Demographic Profile by Age Category}

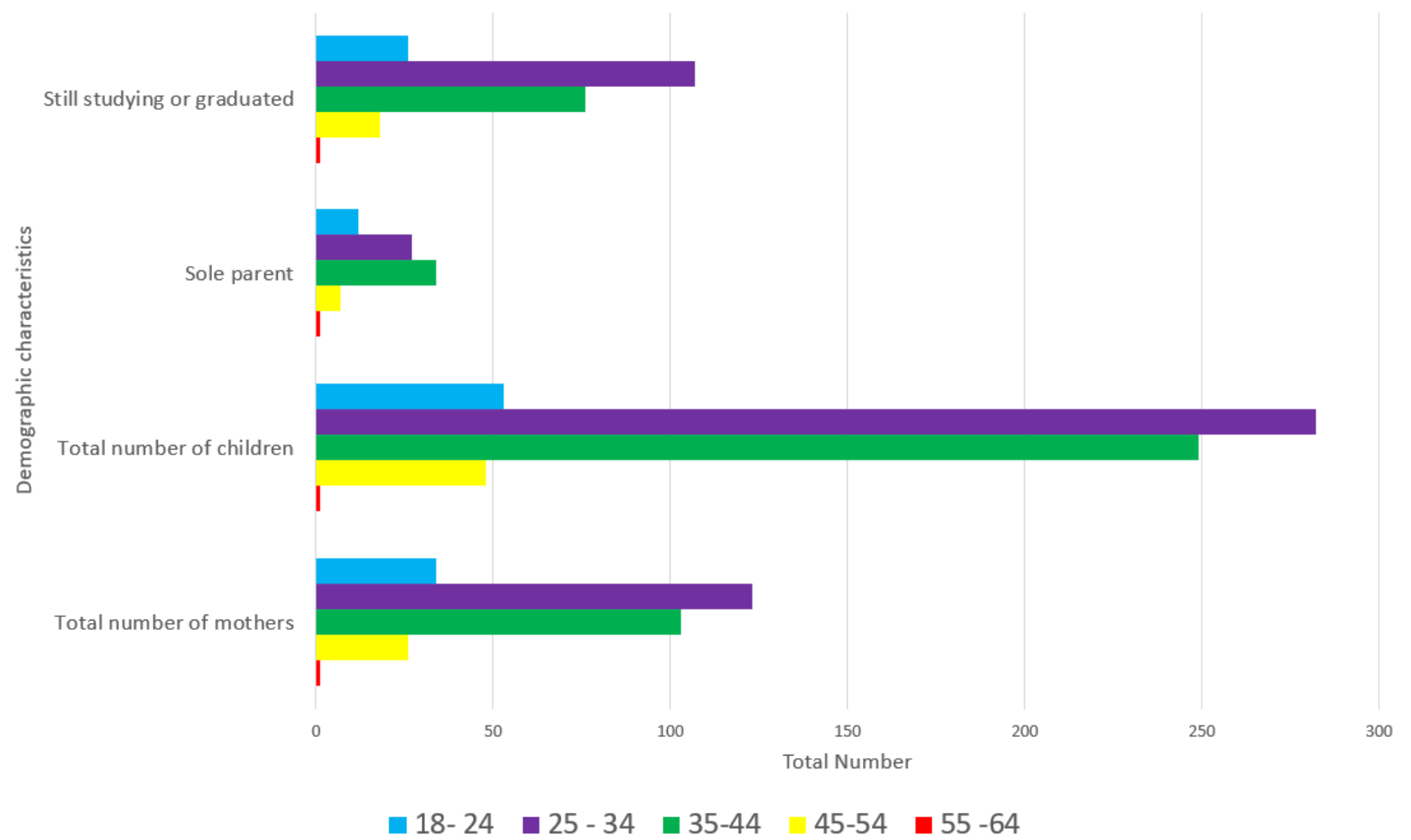

\section{Data Analysis}

To present the individual perspectives of the mothers in this study, the Framework Method provided a systemised thematic approach to analyse the qualitative data (Gale, Heath, Cameron, Rashid \& Redwood, 2013). In this study, Duckworth's (2007) grit conceptual framework was applied across the whole data set to analyse and present the research in a context that was empirical and topical. Applying these categories allowed immersion into the content and deductive clustering of the survey data linked to the grit characteristics. The researchers recorded commonalities, relationships and patterns grouped around the grit concepts and summarised the responses from different parts of the data (Gale et al., 2013). This systematised method increased the traceability and verification of the analysis (Nowell, Norris, White \& Moules, 2017); however, the researchers were mindful of the limitation when applying the Framework Method that the categorisation of content, did not lose the voice and context of the individual participant (Gale, et al, 2013). Retaining the context was achieved by reporting original phrases and expressions using the respondents" own language to share their "lived experiences" and perspectives of their new world of higher education (Armstrong, James, Conradie \& Parker, 2018, p. 13). It was also noted early in the analysis phase, the importance of not excluding data initially viewed as irrelevant to the grit conceptual framework.

\section{Findings}

The women in this study were asked to identify if they perceived they had demonstrated grit characteristics during their enabling (STEPS) studies. Almost 93 per cent acknowledged that they had demonstrated grit at some time or for the whole period of their enabling studies (See Figure 3). 198 mothers stated they demonstrated the characteristics of grit all of the time and 65 mothers perceived they demonstrated these characteristics sometimes during their enabling studies. The mothers described grit as an underlying driving force and determination to succeed: "being at all times committed" and "staying focused". These mothers reported an improved self-efficacy in their capacity to achieve in STEPS through comments such as "feeling confident due to increased knowledge", and "it felt fantastic that I am actually capable to do intellectual work," whilst another stated, "I 
felt empowered". In addition, these mothers commented on their sense of self-pride in what they were accomplishing: "I felt an immense sense of achievement", "STEPS gave me the self-confidence to pursue my dreams."

Only a small number (7.07 per cent) responded that they did not recognise the characteristics of grit in themselves during their enabling studies (see Figure 3). This is reflected in their comments as they predominantly shared negative experiences. These students elaborated that they could not find the capacity to juggle external commitments; were hindered by self-defeating behaviours; and did not have the drive and determination to overcome obstacles that sabotaged their journey. The mothers responded that they did not demonstrate grit as their study experience impacted negatively on them in different ways. For some it was an emotional drain: "I was extremely overwhelmed", "low self-esteem", "multiple challenges", whilst for others they could not find the balance required to manage both study and family commitments: "I struggled with the discipline needed to study", "home life and my time management let me down." For some, it became too much and they could not find the drive to continue and in turn, felt a sense of failure that they did not achieve this goal: "I found myself drowning and falling behind" and "I struggled every day to believe in my own ability to complete STEPS."

\section{Figure 3}

Grit Characteristics Recognised During Enabling Education

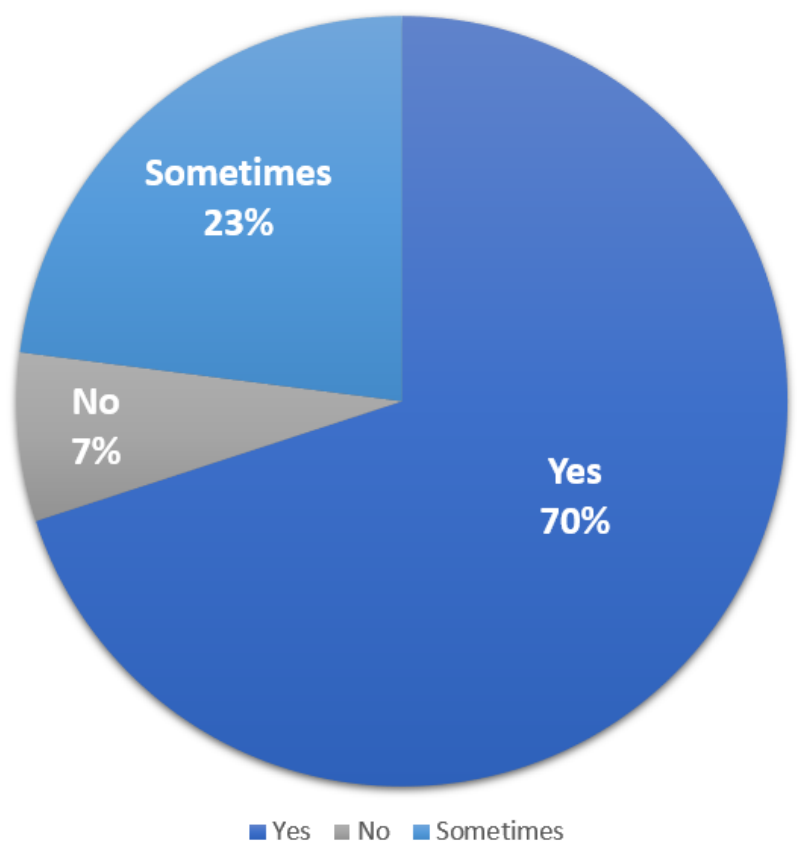

The mothers were asked to rank the grit characteristic that they perceived as the most recognisable in themselves during their enabling studies. Courage was ranked the highest with almost 40 per cent of mothers noting this behaviour as the most obvious grit characteristic during their studies. Endurance and resilience were ranked almost equally, with 18 per cent of respondents ranking them second to courage during their studies. Conscientious behaviours were the fourth-ranked characteristic (13.47 per cent), and the pursuit of excellence was ranked as the least (9.52 per cent) perceptible trait during their enabling studies (see Figure 4). 


\section{Figure 4}

\section{Most Recognisable Grit Characteristic Ranking}

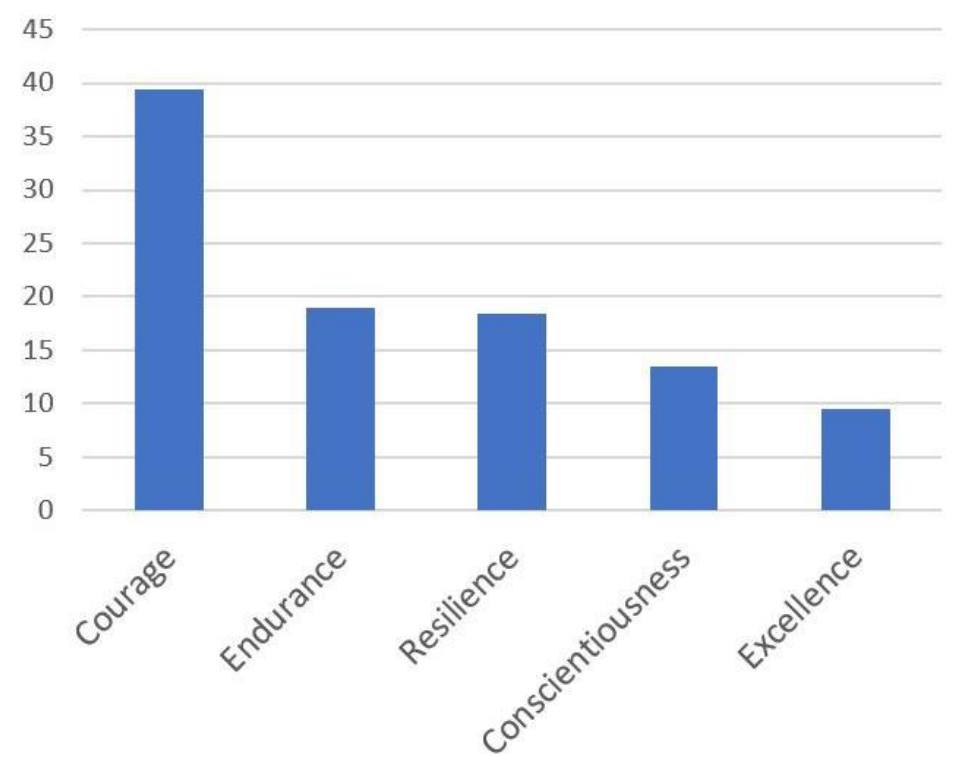

Conversely, the mothers were asked to identify the least recognisable grit characteristics during their enabling studies. Over one-third of the participants (33.7 per cent) ranked the concept of striving for excellence as the least recognisable grit characteristic. Conscientiousness was noted by 21.63 per cent of mothers as the second least recognisable behaviour as an enabling student. Courage (17.07 per cent), resilience (12.11 per cent) and endurance ( 8.7 per cent) were ranked by only a small number of mothers as the characteristics least recognisable during their enabling studies (see Figure 5).

\section{Figure 5}

Least Recognisable Grit Characteristic Ranking

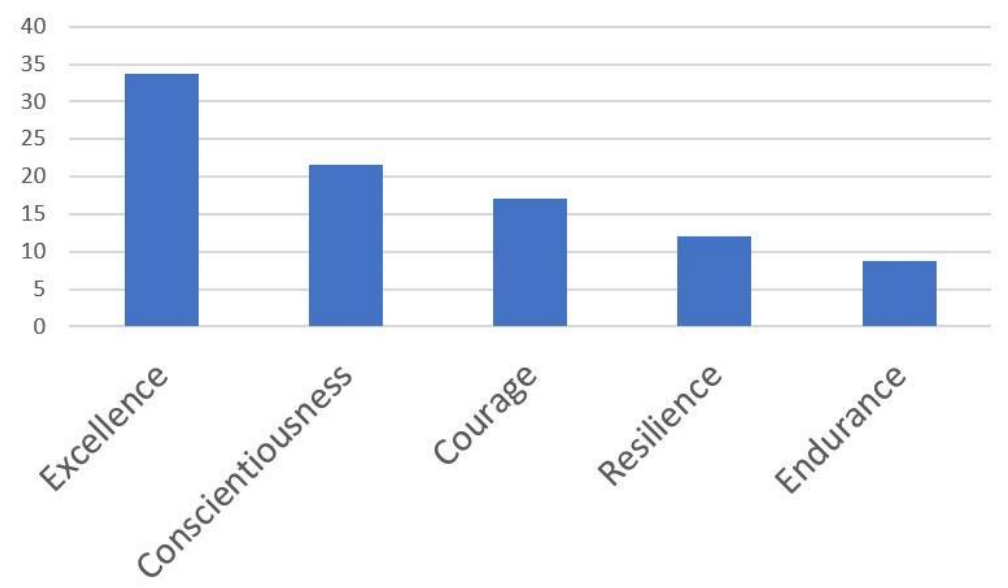

Using the grit concepts, the respondents were asked to describe their experiences during their STEPS studies. Within the characteristic of courage, three key themes emerged: self-belief, self-encouragement and hope for an improved future. Mothers noted how their belief in self strengthened during their study experience. One noted her demonstrated courage by taking "the first step to enrol in the STEPS program" and others used words such as "strength", "courage", "commitment" and "belief in myself" to portray this characteristic. Mothers explained that self-encouragement and a focus on the future gave them the courage to stay engaged: "when I say I cannot do it, I cannot do it "YET", this sets my mind towards trying again instead of 
getting discouraged" whilst others found study an enriching experience: "I loved that I was involved in a journey of selfdevelopment", "all sorts of possibilities is what is driving me to keep going". For some mothers they felt empowered: "goals and a mission in life is a great feeling", with another sharing that "STEPS has allowed me to chase my dream and achieve my goals".

Within the characteristic of conscientiousness, the themes of determination and positive choices emerged. The mothers described their resolve to challenge competing discourses by making decisions to "study over other social engagements" and "determined to make sure I finished." A number of respondents maintained that positive conscientiousness was important when faced with high-level challenges: "I found math quite difficult and had many failures, but I kept working hard", whilst another shared "I just kept on being positive and working through it." Strength and determination were evident in the comments such as "maintaining effort despite adversity." One mother summarised her willpower and positivity stating "my failures and adversities allowed me to grow as a person and see myself become even more determined to succeed."

Within the grit characteristic of resilience, overcoming the fear of failure, managing adversity and optimism about the future were the three key themes that resonated. Mothers shared thoughts around their concern over impending failure and their way of overpowering it: "I had failures but have stayed positive and pushed through", with another saying "adversity either makes you or breaks you. I can choose to see it as a roadblock which prevents me from learning from the experience, or I can see it as a freeway." The mothers' responses described resilience as "maintaining optimism", "being resilient to stress", whilst keeping a hopeful outlook to manage "the ups and downs", noting, "even if I fail I can try again".

The characteristic of endurance emphasised the themes of perseverance and passion; commitment to long term goals; and working to overcome challenges. The mothers reflected on their endurance saying: "I have needed perseverance to find time to study", with another sharing that she realised "it wasn't going to be an overnight success." The theme of sustainable endurance, even when encountering challenges was evident in their comments: "I remind myself of the long term goal of finishing uni" and knowing "it was a long-term commitment", "I'm not going to give up." Mothers shared that their focus on a better future helped them persevere, saying: "I keep my long term goal clearly in my sight" and another clarified that her goals are "always what I am striving for."

The grit characteristic of excellence evidenced themes of self-development, passion for learning and personal satisfaction from achievement. Mothers' perceptions of excellence in STEPS were based on their own measure of quality performance, rather than their university results. They described excellence as enjoyment of learning and recognition of achievement: "I really enjoyed the learning curve", "regardless of grade levels I have received", the importance was to "proved [sic] to myself that I could do it and do it well." An internal drive to maintain excellence during their studies was evident in comments: "pushing myself to achieve well" and "striving to achieve my best." One mother described her experience of excellence as a "passion for studying hard and achieving good results."

\section{Discussion}

Mothers often seek an enabling course as their gateway to a new career and a better future for themselves and their families. The students' experiences shared in this article demonstrate how mothers were able to manage competing discourses during their enabling studies and demonstrate strong personal characteristics to stay engaged and achieve success.

This study identified positive correlations between the application of grit characteristics and academic success and this article will refer to this as 'grit-ability'. The findings showed that the mothers who stayed engaged and successfully completed enabling studies reported higher grit-ability than students who did not complete. Hence showing that a mother's application of grit characteristics in an enabling education environment leads to grit-ability; personal achievement and success. These findings are consistent with those of previous studies (Duckworth et al., 2007; Hodge et al., 2017; Robinson, 2015) showing a positive relationship between grit and academic achievement.

The results of this study support that grit-ability assists mothers to manage competing discourses, overcome challenges and stay engaged to achieve success during their enabling studies. Overwhelmingly, the results showed that grit-ability empowered the mothers to succeed despite balancing children, family, households, work, health, finances, low self-esteem and technology. 
These findings are in accordance with Johnston et al., (2018) asserting that although competing challenges can be stressful, many student mothers thrive under pressure, and through adversity become more self-confident individuals.

When ranking each grit characteristic, it was surprising that courage was the most significant personal characteristic empowering the mothers to stay engaged and work towards academic success. Courage involved taking risks, transformational self-belief, and hope for an improved future. These results match findings observed in other studies where courage undeniably influenced subsequent outcomes (Howard \& Cogswell, 2019; Koerner, 2014). Further, Howard and Cogswell (2019) assert that despite the relationship between courage and outcomes, more research on the antecedents of courage (personality, work experiences, leadership, culture, and demographic factors) is required to determine how courageous traits can be developed (Howard, Farr, Grandey \& Gutworth, 2017). Identifying how to develop courage could benefit enabling education, to design learning environments that foster courageous behaviours and in turn support successful academic outcomes.

Another finding highlighted that the mothers were motivated by hope for a better future. Webb (2013) describes the "pedagogy of hope" as an integral part of human experience, but highlights the difficulty in defining its characteristics and dynamics (p. 397). Giroux (2002) defines hope as "a belief that different futures are possible" and that education can be a pathway to expand these opportunities (cited in McDougall, Holden \& Danaher, 2012, p. 62). The concept of hope is acknowledged in higher education discourse, to support equity and provide "opportunities for those from the margins of society to express their viewpoints and share understandings about the world" (McDougall et al., 2012, p. 63). This sense of hope can have a transformative impact that motivates mothers through "improved self-confidence" and "a more positive attitude" towards future opportunities (Johnston et al., 2018, p. 17). Harrison (2018) proposes that hope is an impetus towards developing "possible selves" and motivates engaged participation from disadvantaged groups in higher education (p. 209).

Interestingly, the grit characteristics of endurance and resilience were ranked almost equally as significant for study success. Enduring perseverance to overcome challenges was recognised as important to avoid discouragement or derailment from long term goals. Likewise, resilience to stress, learning from adversity and an optimistic attitude was highlighted as key for durability towards achievement. The mothers also noted they were mindful of conscientious choices to maintain effort and interest, despite obstacles during their studies. These results align with Dweck's (2006) growth mindset, theorising that some students will rebound after setbacks and that self-belief will motivate students to exert extra time and effort to accomplish higher achievement. Goldberg (1998 cited in Connaughton, Hanton, Jones \& Wadey, 2008) describes this determination as "mental toughness ... the ability to stand tall in the face of adversity ... time and time again" (p. 193). The current findings support that mental toughness is vital to student wellbeing in higher education (Stamp, et al, 2015) and positively related to academic grades (Lin, et al, 2017). The mothers noted improved self-belief during their enabling studies, feeling a sense that they could "control their own destiny" (Clough, Earle \& Sewell, 2002, p. 38). Crust et al. (2014) claim that there are significant and positive correlations between mental toughness and performance, and improved interpersonal confidence was indeed a predictor of enduring academic achievement.

The grit characteristic recognised as least important for success was striving for excellence. The mothers described excellence through personal enjoyment of learning, studying hard and achieving their personal best. None of the respondents described excellence linked to their grades but applied a personal measure of their own success. These findings suggest that for mothers the excellence component of grit-ability is the least motivating towards success. The mothers associated excellence with being a "positive role model", "greater knowledge", "intellectual work", "improved organisation" with one sharing that "my kids think I'm amazing and smart which makes me proud." This accords with Katz's (2018) observations that student mothers achieve with limited resources, especially time and money, and they perceived their own success as the effective "juggling act and identity negotiation that they managed on a near-daily basis" (p. 11). Rowlands (2010) summarised that the various hindrances faced by non-traditional students; managing multiple life roles and responsibilities, have in some cases proven to be beneficial and can be a motivator towards success.

Conversely, some women did not recognise grit-ability in themselves at any time during their enabling studies. These student mothers recounted an inability to cope with competing challenges and low self-esteem. The results of this study indicate that the mothers who are unable to balance multiple commitments become overwhelmed and end up failing and dropping out of their enabling studies (Johnston et al., 2018). The small percentage of mothers who indicated they did not demonstrate gritability have all discontinued studying citing they were unable to overcome the obstacles that sabotaged their journey. These 
findings are consistent with Katz (2018) who noted student mothers sometimes "fell apart" resulting in "burnout, failing or dropping classes" (p. 11).

Grit-ability in this study has shown a positive correlation to achievement, particularly evident when involving high challenges (Crede, Tynan \& Harms, 2016; Duckworth et al., 2007); however, it is a combination of grit characteristics and external factors, that ultimately influence a student's growth and impact success (Rogerson \& Scott, 2010, p. 147). Ryan and Deci (2000) propose their self-determination theory to suggest that students' interest in learning, their value of education and confidence in their own capacities, influence their engagement and academic performance. Other researchers concur that grit characteristics influence student success; acknowledging that grit-ability also requires motivation and self-discipline (Doskoch, 2016; Goodwin \& Miller, 2013) along with a positive environment to support an individual's healthy and productive development (Gray, 2016).

While further investigation is required to better understand the relationship between grit and academic success, this review of research and findings suggest a strong association between grit-ability, levels of engagement and success within the academic environment (Hodge et al., 2017; Robinson, 2015).

\section{Conclusion}

While the connection between dedicated application and achievement is not new, there is a growing volume of research interested in investigating individual personality characteristics that influence success in higher education; however, there is limited research specifically on mothers engaging in enabling education. Duckworth's (2007) characteristics of grit and the intersection with mothers in enabling studies were the focus of this research. The concept of grit-ability has highlighted common themes that contribute to understanding the desirable characteristics that support success within the enabling environment. Mothers in enabling education face barriers that can sabotage study pathways; however, many student mothers thrive under the pressure. The majority of mothers in this study demonstrated significant grit-ability. They displayed the courage to take risks spurred on by hope for their possible futures; conscientiousness in making positive choices to support their academic endeavours; resilience to manage adversity with optimism; endurance to persevere towards long term goals; and a commitment to excellence by striving to achieve their personal best.

\section{References}

Auguste, E., Wai-Ling-Packard, B., \& Keep, A. (2018). Non-traditional women students' experiences of identity recognition and marginalization during advising. NACADA Journal. 38(2), 45-60. https://doi.org/10.12930/NACADA-17-046

Australian Bureau of Statistics [ABS]. (2017). Gender Indicators, Australia, September 2017 (cat. No. 4125.0). http://www.abs.gov.au

Armstrong, F., James, T., Conradie, H., \& Parker, S. (2018). Males in Enabling: Painting a portrait through narrative. Student Success, 9(1), 9-22. https://doi.org/10.5204/ssj.v9i1.429

Baker, S., \& Irwin, E. (2015). A national audit of academic literacies provision in enabling courses in Australian Higher Education. Association for Academic Language and Learning. https://doi.org/10.13140/RG.2.1.1484.5528

Bashant, J. (2014). Developing grit in our students: why grit is such a desirable trait, and practical strategies for teachers and schools. Journal for Leadership and Instruction, 13(2), 14-17.

Bazelais, P., Lemay, D., \& Doleck, T. (2016). How does grit impact college students' academic achievement in science? European Journal of Science and Mathematics Education, 4(1), 33-43.

Bazelais, P., Lemay, D., Doleck, T., Hu, X., \& Yao, J. (2018). Grit, mindset, and academic performance: A study of preuniversity science students. Eurasia Journal of Mathematics, Science and Technology Education, 14(12), https://doi.org/10.29333/ejmste/94570

Buskirk-Cohen, A., \& Plants, A. (2019). Caring About Success: Students' perceptions of professors' caring matters more than grit. International Journal of Teaching and Learning in Higher Education, 31(1), 108-114 
Cicchetti, D. (2013). Annual Research Review: Resilient functioning in maltreated children - past, present and future perspectives. Journal Child Psychology Psychiatry, 54(4), 402-422. https://doi.org/10.1111/j.1469-7610.2012.02608.x

Clough, P., Earle, K., \& Sewell, D. (2002). Mental toughness: The concept and its measurement. Solutions in Sport Psychology, 32(46). https://www.researchgate.net/publication/313119986

Connaughton, D., Hanton, S., Jones, G., \& Wadey, R. (2008). Mental toughness research: Key issues in this area. International Journal Sport Psychology, 39(3), 192-204. https://www.researchgate.net/publication/298858052

Crede, M., Tynan, M., \& Harms, P. (2016). Much ado about grit: A meta-analytic synthesis of the grit literature. Journal of Personality and Social Psychology, 113(3). 492-511. https://psycnet.apa.org/doi/10.1037/pspp0000102

Crust, L., Earle, K., Perry, J., Earle, F., Clough, A., \& Clough, P. (2014). Mental toughness in higher education: Relationships with achievement and progression in first-year university sports students. Personality and Individual Differences. 69, 87-91. https://doi.org/10.1016/j.paid.2014.05.016

Doskoch, P. (2016, June 9). The winning edge. Psychology Today. https://www.psychologytoday.com/au/articles/200511/thewinning-edge

Duckworth, A., Peterson, C., Matthews, M., \& Kelly, D. (2007). Grit: Perseverance and passion for long-term goals. Journal of Personality and Social Psychology, 92(6), 1087-1101. https://psycnet.apa.org/doi/10.1037/0022-3514.92.6.1087

Duckworth, A., Quinn, P., \& Seligman, M. (2009). Positive predictors of teacher effectiveness. The Journal of Positive Psychology, 4(6), 540-547. http://dx.doi.org/10.1080/17439760903157232

Dweck, C. (2017). Decades of Scientific Research that Started a Growth Mindset Revolution. https://www.mindsetworks.com/science/

Enkhtur, A., \& Yamamoto, B. (2017). Transformative learning theory and its application in higher education settings: A review paper. Osaka University. https://doi.org/10.18910/60584

Farrington,_C., Roderick, M., Allensworth, E., Nagaoka, J., Keyes, T., Johnson, D., \& Beechum, N. (2012). Teaching adolescents to become learners: The role of noncognitive factors in shaping school performance -- A critical literature review. University of Chicago Consortium.

https://www.academia.edu/7114063/Teaching_Adolescents_to_Become_Learners_CCSR

Gale, N., Heath, G., Cameron, E., Rashid, S., \& Redwood, S. (2013). Using the framework method for the analysis of qualitative data in multi-disciplinary health research. BMC Medical Research Methodology, 13, 117. https://doi.org/10.1186/1471-2288-13-117

Goodwin, B., \& Miller, K. (2013). Research says / grit plus talent equals student success. Resilience and Learning, 71(1), 7476. http://www.ascd.org/publications/educational-leadership/sept13/vol71/num01/Grit-Plus-Talent-Equals-StudentSuccess.aspx

Hardin, C. J. (2008). Adult students in higher education: A portrait of transitions. New Directions for Higher Education, 144, 49-57. https://doi.org/10.1002/he.325

Hodge, B., Wright, B., \& Bennett, P. (2017). The role of grit in determining engagement and academic outcomes for university students. Research in Higher Education, 59(4), 448-460. http://doi.org/10.1007/s11162-017-9474-y

Howie, P., \& Bagnall, R. (2013). A beautiful metaphor: Transformative learning theory. International Journal of Lifelong Education, 32(6), 816-836. https://doi.org/10.1080/02601370.2013.817486

Howard. M., \& Cogswell, J. (2019). The left side of courage: Three exploratory studies on the antecedents of social courage. Journal of Positive Psychology, 14(3), 324-340. https://doi.org/10.1080/17439760.2018.1426780

Howard, M., Farr, J., Grandey, A., \& Gutworth, M. (2017). The creation of the Workplace Social Courage Scale (WSCS): An investigation of internal consistency, psychometric properties, validity, and utility. Journal of Business and Psychology, 32(6), 673-690. https://doi.org/10.1007/s10869-016-9463-8

John, O., Naumann, L., \& Soto, C. (2008). Paradigm shift to the integrative big-five trait taxonomy: History, measurement, and conceptual issues. In O. John, R. Robins, \& L. Pervin (Eds.), Handbook of Personality: Theory and Research (pp. 114-158). Guilford Pres

Johnston, K., James, T., Braund, A., \& Mullaney, L. (2018, November 29-30). Mothers in enabling: Overcoming challenges to become better role models and an inspiration to their families [paper presentation]. Foundations and Bridging Educators New Zealand, Wellington, New Zealand. http://fabenz.org.nz/proceedings-of-the-fabenz-conference-2018/

Jones, L. (2018). Grit and Stress: Predictors of African American Success? Texas A \& M University. https://eric.ed.gov/?id=ED588937

Hagedorn, L. (2006). How to define retention: A new look at an old problem. https://eric.ed.gov/?id=ED493674

Harrison, N. (2018) Using the lens of 'possible selves' to explore access to higher education: A new conceptual model for practice, policy, and research. Social Sciences, 7(10), 209-230. https://doi.org/10.3390/socsci7100209

Kannangara, C., Allen, R., Waugh, G., Nahar, N., Khan, S., Rogerson, S., \& Carson, J. (2018). All that glitters is not grit: Three studies of grit in university students. Frontiers in Psychology, 9, 1539. https://doi.org/10.3389/fpsyg.2018.01539

Katz, S. (2018). Pride and hope, shame and blame: How welfare mothers in higher education juggle competing identities. In T. Taylor \& K Bloch (Eds.), Marginalized Mothers, Mothering from the Margins (pp.11-24). Emerald Publishing. 
Khabanyane, K., Maimane, J., \& Ramabenyane, M. (2014). A critical reflection on transformative learning as experienced by student-teachers during school-based learning. Mediterranean Journal of Social Sciences, 5(27), 452-460. https://doi.org/:10.5901/mjss.2014.v5n27p452

Koerner, M. (2014). Courage as identity work: Accounts of workplace courage. Academy of Management Journal, 57(1), 6393. https://doi.org/10.5465/amj.2010.0641

Lopez, S., O'Byrne, K., \& Petersen, S. (2003). Profiling courage. In S. Lopez \& C. Snyder (Eds.), Positive psychological assessment: A handbook of models and measures (pp. 185-197). American Psychological Association. http://dx.doi.org/10.1037/10612-012

McDougall, J., Holden, H., \& Danaher, G. (2012). Pedagogy of hope: The possibilities for social and personal transformation in an academic language and learning curriculum. Journal of Academic Language and Learning, 6(3), 59-69.

Mezirow, J., \& Taylor, E. (2011). Transformative Learning in Practice: Insights from Community, Workplace, and Higher Education. John Wiley \& Sons, Inc.

Nagaoka, J., Farrington, C., Roderick, M., Allensworth, E., Keyes, T., Johnson, D., \& Beechum, N. (2013). Readiness for college: The role of noncognitive factors and context. Voices in Urban Education, (38). 45-52.

National Centre for Student Equity in Higher Education. (2019). Equity data [Fact sheet]. https://www.ncsehe.edu.au/data/

Nowell, L., Norris, J., White, D., \& Moules, N. (2017). Thematic analysis: Striving to meet the trustworthiness criteria. International Journal of Qualitative Methods, 16(1), 1-13. https://doi.org/10.1177/1609406917733847

Pate, A., Payakachat, N., Harrell, T., Pate, K., Caldwell, D., \& Franks, A (2017). Measurement of grit and correlation to student pharmacist academic performance. American Journal of Pharmaceutical Education, 81(6), 1-8. https://dx.doi.org/10.5688\%2Fajpe816105

Perlis, M. (2013, October 29). 5 characteristics of grit - How many do you have? Forbes. https://www.forbes.com/sites/margaretperlis/2013/10/29/5-characteristics-of-grit-what-it-is-why-you-need-it-and-do-youhave-it/\#41bfd7584f7b

Pitman, T., Roberts, L., Bennett, D., \& Richardson, S. (2017). An Australian study of graduate outcomes for disadvantaged students, Journal of Further and Higher Education, 43(1), 45-57. https://doi.org/10.1080/0309877X.2017.1349895

Poropat, A. (2009). A meta-analysis of the five-factor model of personality and academic performance. Psychological Bulletin, 135, 322-338. http://dx.doi.org/10.1037/a0014996

Quimby, J., \& O'Brien, K. (2006). Predictors of well-being among non-traditional female students with children. Journal of Counselling and Development, 48, 451-460. https://doi.org/10.1002/j.15566678.2006.tb00429.x

Roberts, B., Lejuez, C., Krueger, R., Richards, J., \& Hill, P. (2014). What is conscientiousness and how can it be assessed? Developmental Psychology, 50(5), 1315-30. https://doi.org/10.1037/a0031109

Rogerson, C., \& Scott, E. (2010). The fear factor: How it affects students learning to program in a tertiary environment, Journal of Information Technology Education: Research, 9(1), 1-25. https://www.learntechlib.org/p/111361/

Rowlands, S. (2010). Non-traditional students: The impact of role strain on their identity. Southern Illinois University, USA. https://ehs.siu.edu/wed/_common/documents/graduate/sample-literature-review.pdf

Ryan, R., \& Deci, E., (2000). Self-determination theory and the facilitation of intrinsic motivation, social development, and well-being. The University of Rochester. https://selfdeterminationtheory.org/SDT/documents/2000_RyanDeci_SDT.pdf

Shechtman, N., DeBarger, A., Dornsife, C., Rosier, S., \& Yarnall, L. (2013). Promoting grit, tenacity, and perseverance: Critical factors for success in the 21st century. Students at the Centre Hub. https://studentsatthecenterhub.org/resource/promoting-grit-tenacity-and-perseverance-critical-factors-for-success-in-the21st-century/

Stewart, S (2015). Grit and self-control as predictors of first-year student success. University of Southern Maine Digital Commons. https://digitalcommons.usm.maine.edu/cgi/viewcontent.cgi?referer=https://www.google.com/\&httpsredir=1\&article=1172 \&context=etd

Universities Australia. (2019). Data snapshot [Fact sheet]. https://www.universitiesaustralia.edu.au/wpcontent/uploads/2019/06/Data-snapshot-2019-FINAL.pdf

Wallace, R. (2015). Grit and student performance: A mixed-method analysis of a non-traditional technical high school and a traditional high school. Lindenwood University. https://pqdtopen.proquest.com/doc/1775742276.html?FMT=ABS

Webb, D. (2013) Pedagogies of Hope. Studies in Philosophy and Education, 32(4), 397-414. https://doi.org/10.1007/s11217012-9336-1

Wild, K (2014) Non-traditional centers : Promoting non-traditional student success in higher education, Kansas State University. https://krex.k-state.edu/dspace/bitstream/handle/2097/17330/KelleyWild2014.pdf; sequence=5

Wolters, C., \& Hussain, M. (2015). Investigating grit and its relations with college students' self-regulation learning and academic achievement. Metacognition and Learning, 10(3), 293-311. https://eric.ed.gov/?id=EJ1081602

Zolli, A., \& Healy, A (2012). Resilience: Why things bounce back. https://ssir.org/books/reviews/entry/suggestive_evidence\# 


\section{Please cite this article as:}

Braund, A., James, T., Johnston, K., \& Mullaney, L. (2020). Grit-ability: Which grit characteristics enable success for mothers entering university? Student Success, 11(1), 22-34. https://doi.org/10.5204/ssj.v11i1.1457

This article has been peer reviewed and accepted for publication in Student Success. Please see the Editorial Policies under the 'About' section of the Journal website for further information.

Student Success: A journal exploring the experiences of students in tertiary education

(c) $\stackrel{\text { (i) }}{\text { iv }}$ This work is licensed under a Creative Commons Attribution 4.0 International Licence. As an open access journal, articles are free to use with proper attribution. ISSN: 2205-0795 